\title{
GAMBARAN PENYAKIT PERLEMAKAN HATI NON-ALKOHOLIK PADA PASIEN HIPERTENSI YANG MEMPUNYAI SGPT MENINGKAT
}

\author{
${ }^{1}$ Nathania P. Rengkung \\ ${ }^{2}$ Bradley J. Waleleng \\ ${ }^{2}$ Stella Palar
}

\author{
${ }^{1}$ Kandidat Skripsi Fakultas Kedokteran Universitas Sam Ratulangi Manado \\ ${ }^{2}$ Bagian Ilmu Penyakit Dalam Fakultas Kedokteran Universitas Sam Ratulangi Manado \\ Email: nrengkung11_070@yahoo.com
}

\begin{abstract}
Non alcoholic fatty liver disease (NAFLD) is a clinical pathologic condition that is signed by increasing of transaminase enzyme serum level and hepatic steatosis without any history of alcohol consuming. Essential hypertension is associated with the metabolic syndrome, insulin resistance and the development of fatty liver. This study aimed to obtain the description of NAFLD in hypertensive patients that had elevation of SGPT. This was a prospective study conducted in Renal Hypertension Clinic Prof. Dr. R. D. Kandou Hospital Manado from November 2014 until January 2015. The results showed that there were 31 hypertensive patients; 21 cases were diagnosed with NAFLD. Females were more frequent than males and the age group 51-60 years was the most frequent (38.1\%). Mild fatty liver was found in 17 cases, moderate in 3 cases, and severe in 1 case. Conclusion: In this study, non alcoholic fatty liver disease in hypertensive patients affected females more than males in the age group of 51-60 years old. Mild fatty liver was the most common USG result among the patients.
\end{abstract}

Keywords: non-alcoholic fatty liver disease (NAFLD), essential hypertension, USG

\begin{abstract}
Abstrak: Penyakit perlemakan hati non-alkoholik merupakan klinikopatologik yang ditandai oleh kenaikan kadar enzim transaminase serum dan steatosis hepatik tanpa adanya riwayat konsumsi alkohol. Hipertensi esensial diketahui terkait dengan sindrom metabolik, yang ditandai adanya resistensi insulin, dan perkembangan perlemakan hati (steatosis hati). Penelitian ini dilakukan untuk mengetahui gambaran NAFLD pada pasien hipertensi dengan SGPT meningkat. Penelitian ini menggunakan metode prospektif dan dilakukan terhadap pasien hipertensi di Poliklinik Ginjal Hipertensi RSUP Prof. Dr. R. D. Kandou Manado dari bulan November 2014 - Januari 2015. Pada penelitian ini didapatkan 31 pasien hipertensi; 21 kasus pasien yang didiagnosis NAFLD. Hasil penelitian memperlihatkan bahwa dari 21 kasus NAFLD didapatkan pasien perempuan lebih banyak daripada laki-laki, dengan usia terbanyak 51-60 tahun (38,1\%). Derajat perlemakan hati ringan ditemukan pada 17 kasus; derajat sedang 3 kasus; dan derajat berat 1 kasus. Simpulan: Penyakit perlemakan hati nonalkoholik pada pasien hipertensi banyak diderita oleh perempuan dengan kelompok umur 51-60 tahun. Derajat perlemakan hati ringan sebagai gambaran USG tersering pada pasien hipertensi.
\end{abstract}

Kata kunci: non-alcoholic fatty liver disease (NAFLD), hipertensi esensial, USG 
Penyakit perlemakan hati non-alkoholik atau non-alcoholic fatty liver disease (NAFLD) merupakan spektrum kondisi yang ditandai secara histologis dengan steatosis (perlemakan) hati makrovesikular dan terjadi pada mereka yang tidak mengkonsumsi alkohol yang berat. Ada dua pola histologis NAFLD, yaitu lemak hati saja (non alcoholic fatty liver $=$ NAFL) dan perlemakan hati pada tingkat yang lebih berat (nonalcoholic steatohepatitis = NASH). ${ }^{1}$ Dikatakan sebagai perlemakan hati apabila kandungan lemak di hati (sebagian besar terdiri atas trigliserida) melebihi 5\% dari seluruh berat hati. ${ }^{2}$ Terdapat peningkatan insidensi NAFLD pada sindroma metabolik yang meliputi obesitas, hiperinsulinemia, resistensi insulin perifer, diabetes mellitus, hipertrigliseridemia, dan hipertensi. ${ }^{3}$

Lesmana melaporkan 17 pasien steatohepatitis non alkoholik di Indonesia, rata-rata berumur 42 tahun dengan 29\% gambaran histologi hati menunjukkan steatohepatitis disertai fibrosis. Sebuah studi populasi dengan sampel cukup besar oleh Hasan dkk mendapatkan prevalensi NAFLD sebesar $30,6 \%{ }^{2}$ Prevalensi NAFLD tertinggi adalah pada usia 40-49 tahun. $^{4}$ _ Gejala klinik dari NAFLD seringkali tidak khas, dapat tanpa gejala (asimtomatik) atau dengan gejala, diantaranya keluhan pada perut dan gangguan toleransi fisik. ${ }^{5-7}$ Pada pemeriksaan fisik dapat ditemukan obesitas sentral, hepatomegali, dan hipertensi. Diagnosis NAFLD dalam klinik biasanya ditegakkan dengan berbagai pemeriksaan penunjang, antara lain: pencitraan hati (USG, CT scan, MRI, fibroscan), pemeriksaan laboratorium (AST, ALT, dll), dan histopatologi hati dari biopsi hati. Pada pasien NAFLD, dapat dijumpai adanya kenaikan kadar AST, ALT. Gambaran khas USG hati pada pasien NAFLD adalah: hiperekogenik hati yang difus (bright liver) dibanding ginjal. ${ }^{8}$

Hipertensi didefinisikan sebagai tekanan darah sistolik $\geq 140 \mathrm{mmHg}$ atau tekanan darah diastolik $\geq 90 \mathrm{mmHg}$. Hipertensi yang tidak diketahui penyebabnya disebut hipertensi esensial atau hipertensi primer, untuk membedakannya dengan hipertensi lain yang sekunder karena sebab-sebab yang diketahui. $^{2}$ Faktor-faktor resiko yang mendorong timbulnya kenaikan tekanan darah tersebut ialah: diet dan asupan garam, stes, ras, obesitas, merokok, genetik, sistem saraf simpatis (tonus simpatis, variasi diurnal). ${ }^{3}$

Non-alcoholic fatty liver disease merupakan faktor resiko independen untuk hipertensi. Hipertensi esensial diketahui terkait dengan sindrom metabolik, yang ditandai dengan resistensi insulin, dan pengembangan perlemakan hati (steatosis hati). ${ }^{4}$ Kelompok hipertensi ditemukan resisten insulin dengan tingkat lebih tinggi dari insulin plasma, membenarkan bahwa hipertensi esensial bagian dari sindrom resistensi insulin. Adanya resistensi insulin tampaknya terlibat dalam patogenesis komplikasi yang berhubungan dengan hipertensi. Meskipun hipertensi telah dikaitkan dengan perkembangan NAFLD parah pada pasien obesitas, hipertensi, dan perlemakan hati juga dikaitkan pada populasi non-obesitas. ${ }^{4}$ Penelitian ini bertujuan untuk mengetahui gambaran NAFLD pada pasien hipertensi yang mempunyai SGPT meningkat di RSUP Prof. Dr. R.D. Kandou Manado.

\section{METODE PENELITIAN}

Penelitian ini menggunakan desain deskriptif potong lintang, dilakukan di Poliklinik Ginjal Hipertensi RSUP Prof. Dr. R. D. Kandou Manado dari bulan November 2014 - Januari 2015. Populasi penelitian ialah pasien hipertensi dewasa dan sampel penelitian ialah pasien hipertensi dewasa dengan SGPT meningkat. Penelitian dilakukan dalam 4 tahap. Tahap ke-1 mengumpulkan pasien hipertensi dengan bentuk tubuh kurus dan normal. Pasien yang memenuhi kriteria diberi penjelasan tentang penelitian, dan bila bersedia, diminta menandatangani informed consent, pencatatan identitas pasien, lalu mengukur berat badan dan tinggi badan pasien untuk mendapatkan 
IMT. Tahap ke-2, dilakukan pemeriksaan laboratorium (GDP, SGOT, SGPT, Total Cholesterol, HDL Cholesterol, LDL Cholesterol, Trigliserida) guna memenuhi kriteria inklusi. Tahap ke-3, melakukan pemeriksaan USG pada pasien hipertensi. Tahap ke-4, dilakukan pengolahan dan analisis data dengan program Statistics Package for the Social Science versi 22.0.

\section{HASIL PENELITIAN}

Berdasarkan penelitian yang dilakukan di RSUP Prof. Dr. R. D. Kandou Manado periode November 2014 - Januari 2015, dari 31 pasien hipertensi didapatkan 21 kasus pasien NAFLD yang dijadikan sampel penelitian. Data penelitian diolah secara kualitatif dengan metode univariat.

Tabel 1. Distribusi Frekuensi Kategori Untuk Pasien Hipertensi Berdasarkan Jenis Kelamin

\begin{tabular}{ccc}
\hline Jenis Kelamin & $\begin{array}{c}\text { Frekuensi } \\
\text { (f) }\end{array}$ & \% \\
\hline L & 11 & 35 \\
$\mathbf{P}$ & 20 & 65 \\
Total & 31 & 100 \\
\hline
\end{tabular}

Tabel 2. Distribusi Frekuensi Kategori Untuk Pasien NAFLD Berdasarkan Jenis Kelamin

\begin{tabular}{ccc}
\hline $\begin{array}{c}\text { Jenis } \\
\text { Kelamin }\end{array}$ & $\begin{array}{c}\text { Frekuensi } \\
\text { (f) }\end{array}$ & \% \\
\hline $\mathrm{L}$ & 7 & 33 \\
$\mathrm{P}$ & 14 & 67 \\
Total & 21 & 100 \\
& & \\
\hline
\end{tabular}

Tabel 3. Distribusi Frekuensi Kategori Untuk Pasien Hipertensi Berdasarkan Umur

\begin{tabular}{ccc}
\hline $\begin{array}{c}\text { Kelompok umur } \\
\text { (tahun) }\end{array}$ & Frekuensi & $\%$ \\
\hline $41-50$ & 6 & 19,3 \\
$51-60$ & 10 & 32,3 \\
$61-70$ & 10 & 32,3 \\
$71-83$ & 5 & 16,1 \\
Total & 31 & 100 \\
\hline
\end{tabular}

Tabel 4. Distribusi Frekuensi Untuk Pasien NAFLD Berdasarkan Umur

\begin{tabular}{ccc}
\hline $\begin{array}{c}\text { Kelompok umur } \\
\text { (tahun) }\end{array}$ & Frekuensi & $\%$ \\
\hline $41-50$ & 3 & 14,3 \\
$51-60$ & 8 & 38,1 \\
$61-70$ & 6 & 28,6 \\
$71-83$ & 4 & 19,0 \\
Total & 21 & 100 \\
\hline
\end{tabular}

Tabel 5. Distribusi Frekuensi Untuk Pasien NAFLD Berdasarkan USG

\begin{tabular}{ccc}
\hline $\begin{array}{c}\text { Derajat } \\
\text { perlemakan hati }\end{array}$ & Frekuensi & $\%$ \\
\hline Ringan & 17 & 81 \\
Sedang & 3 & 14,3 \\
Berat & 1 & 4,8 \\
Total & 21 & 100
\end{tabular}

\section{BAHASAN}

Kriteria sampel yang diteliti ialah semua pasien hipertensi dengan NAFLD, berdasarkan pemeriksaan USG abdomen, dimana telah diambil 21 sampel penelitian.

Hasil penelitian menunjukkan bahwa selama periode November 2014 - Januari 2015 di RSUP Prof. Dr. R. D. Kandou Manado terdapat 31 pasien dengan 21 kasus pasien yang didiagnosis NAFLD. Dari 21 kasus NAFLD didapatkan pasien laki-laki 7 orang (33\%) dan pasien perempuan 14 orang (67\%). Persentase jenis kelamin berbeda-beda dalam berbagai penelitian, namun umumnya menunjukkan adanya predileksi perempuan yang juga berkaitan dengan NAFLD. ${ }^{9}$

Berdasarkan kelompok umur, sebagian besar pasien NAFLD masuk dalam kelompok umur 51-60 tahun yakni 38,1\% dan kelompok usia 61-70 tahun yakni 28,6\%. Menurut AGA (2002) prevalensi NAFLD meningkat sesuai dengan peningkatan umur. ${ }^{10}$

Gambaran USG perlemakan hati pasien NAFLD dibedakan dalam 3 derajat, yakni perlemakan hati ringan, sedang, dan berat. Dari 21 kasus NAFLD pada pasien hipertensi didapatkan derajat perlemakan hati ringan 17 kasus (81\%), derajat sedang 
3 kasus (14,3\%), dan derajat berat 1 kasus (4,8\%). Menurut Andrada PL dan Tan Jose, hipertensi esensial juga berhubungan erat dengan SM, resistensi insulin, dan NAFLD. ${ }^{11}$

\section{SIMPULAN}

Penyakit perlemakan hati nonalkoholik pada pasien hipertensi banyak diderita oleh perempuan, pada kelompok umur 51-60 tahun. Derajat perlemakan hati ringan sebagai gambaran USG tersering pada pasien hipertensi.

\section{SARAN}

1. Perlunya penelitian yang lebih mendalam mengenai gejala klinik NAFLD sehingga dapat diketahui perkembangan penyakit ini dan juga dapat dilakukan penanganan yang lebih spesifik.

2. Perlunya dilakukan pemeriksaan dini dan penanganan pada pasien hipertensi yang berisiko menderita NAFLD.

3. Menambah jumlah sampel pasien nonhipertensi untuk dilakukan pemeriksaan ultrasonografi dan dibandingkan kejadian NAFLD pada pasien hipertensi dan kejadian NAFLD pada pasien non-hipertensi.

\section{DAFTAR PUSTAKA}

1. Mamun AM, Sheikh FA. Non-alcoholic Fatty Liver Disease A Review. Journal of Gastroenterology and Hepatology Research, 2013.

2. Sudoyo AW. In: Sudoyo AW, Bambang S, Idrus A, Marcellus SK, Siti S, editors. Buku Ajar Ilmu Penyakit Dalam. Jilid I Edisi V. Jakarta: Interna Publishing Pusat Penerbitan Ilmu Penyakit Dalam, 2009.

3. Kim DD, et al. Mechanisms of
Acupuncture and Herbal Medicine in Hypertension. Asian Biomedicine 2008;2(4):257-74.

4. Lesmana. Perlemakan Hati NonAlkoholik. In: Sudoyo AW, Bambang S, Idrus A, Marcellus SK, Siti S, editors. Buku Ajar Ilmu Penyakit Dalam Jilid I (Ed. V). Jakarta: Interna Publishing Pusat Penerbitan Ilmu Penyakit Dalam, 2009; p. 695.

5. Lesmana LA. Penyakit Perlemakan Hati Non-Alkoholik (Non-Alcoholic Fatty Liver Disease). In: Sulaiman A, Akbar N, Lesmana LA, Noer HMS (Editors). Buku Ajar Ilmu Penyakit Hati. Jakarta: Jaya Abadi, 2007; p. 301-5.

6. Salt WB. Nonalcoholic Fatty Liver Disease (NAFLD): A Comprehensive Review. J. Insur Med 2004;36:27-41.

7. Adams LA, Angulo $\mathbf{P}$, Lindor KD. Nonalcoholic fatty liver disease. CMAJ. 2005;172(7):899-905.

8. Hasan I. Perlemakan Hati Non Alkoholik. In: Sudoyo AW, Setyohadi B, Alwi I, Simadibrata MK, Setiati S. (Editors). Buku Ajar Ilmu Penyakit Dalam (4th ed). Jakarta: Pusat Penerbit Ilmu Penyakit Dalam FK UI, 2006; p. 464-72.

9. Sanyal AJ. Nonalcoholic fatty liver disease. In: Yamada $\mathrm{T}$, editor. Textbook of gastroenterology Volume 1 (5 $^{\text {th }}$ ed). Chichester: Wiley-Blackwell Publishing, 2009; p. 2274-2301.

10. AGA. Technical Review on Nonalcoholic Fatty Liver Disease, Gastronterol. 2002;123:1705-25.

11. Andrada PL, Tan J. Prevalence of Metabolic Syndrome among patients with Non-Alcoholic Liver Disease. Phil J Gastroenterol 2006;2:14-18. 